\title{
PERAN FILSAFAT \\ ISLAM DALAM MEMBANGUN TRADISI KEILMUAN
}

\begin{abstract}
Husain Heriyanto
Sadra International Institute Jakarta; Program Pascasarjana Universitas Indonesia; the Islamic College for Advanced Studies (ICAS) Jakarta; the Avicenna Center for Religion and Science Studies (ACRoSS)
\end{abstract}

\begin{abstract}
Treasures of classical and contemporary Islamic philosophy is very rich indeed. Unfortunately, until now this intellectual property is still stored in the libraries. The Avicenna's thought as a genius philosopher, for instance, was not explored all, especially the eventual development of such thinking in Tanbîhât wa al-Manthiq al-Masyriqiyyah (East Logic). Not many people know how Ibn Sina solved the problems of scientific and philosophical methods are also through meditation and prayer, long before Quantum Learning was excited. The specificity of Islamic philosophy is a comprehensive and integrated way to study the metaphysics, epistemology, ethics, cosmology, and psychology. In this paper the authors highlight how the role of philosophy in building a scientific tradition. Science that not only develop the advancement of science alone, but also spawned generations aware of his existence and humanity.
\end{abstract}

Kata kunci: filsafat Islam, tradisi keilmuan, integrasi ilmu, klasifikasi ilmu

\section{Pendahuluan}

Saya mulai tertarik dengan isu tradisi keilmuan Islam dalam konteks Indonesia setelah menyimak ceramah-ceramah almarhum Nurcholish Madjid. Pemikiran Cak Nur -panggilan akrab tokoh intelektual Muslim Indonesia ini- sudah saya kenal sejak aktif di HMI, sebuah organisasi mahasiswa terbesar di Indonesia yang beliau pimpin selama dua periode (1966-1971). Penulis Khasanab Intelektual Muslim (Jakarta, 1994) ini dan juga sejumlah karya lain yang terkait dengan peradaban Islam, yang diantaranya menjadi referensi buku ini, selalu bersemangat ketika membicarakan prestasi ilmiah para ilmuwan Muslim pada masa keemasan peradaban Islam, dan pada saat yang sama sangat memprihatinkan kondisi umat Islam sekarang. Izinkan saya mengutip salah satu penggalan tulisan beliau,

Yang lebih diperlukan ialah penumbuhan dan pengembangan etos keilmuan yang kuat dan mendalam, yang menghasilkan kesadaran bahwa ilmu pengetahuan bukan saja berguna untuk memenuhi expediency dan menjawab tantangan-tantangan ad hoc, melainkan merupakan bagian dari pandangan hidup. Dan pandangan hidup itu, untuk seorang Muslim dan umat Islam, tentu tidak dapat lain kecuai mesti berdasarkan ajaran Islam. Jadi, yang amat diperlukan adalah sebuah etos yang mampu melihat hubungan organik antara ilmu dan iman. Tetapi justru ini yang nampaknya belum tumbuh dengan mantap di kalangan kaum Muslim. ${ }^{1}$

\section{Untuk Apa?}

Apa manfaat dan relevansi pengembangan tradisi keilmuan Islam dalam konteks umat Islam sekarang? Sejauh manakah urgensi kajian historis dan filosofis tersebut dengan problema sosial budaya 
umat Islam hari ini? Dengan kata lain, apa manfaat gagasan ini untuk umat Islam Indonesia khususnya dan umat manusia umumnya?

Saya hendak menjawabnya dalam konteks sosial umat Islam hari ini bahwa pengenalan tradisi keilmuan Islam secara historis ikut menumbuhkan kesadaran peradaban pada diri kaum Muslim bahwa di satu sisi mereka memiliki kebanggaan sebagai umat yang berjasa mengembangkan ilmu pengetahuan dan peradaban dunia dan di lain sisi kesadaran ini mendorong mereka untuk memiliki tanggung jawab terhadap peradaban dunia, yang pada gilirannya akan menghilangkan mentalitas 'luar pagar' (perasaan terasing dan tersisihkan dari peradaban dunia) yang dialami sejumlah kaum Muslim radikal. Ekstrimisme dan kekerasan atas nama agama, dilihat dari perspektif sosio-budaya, merupakan efek samping dari mentalitas 'luar pagar' ini. Izinkan saya mengulasnya secara ringkas dengan mengkombinasikan analisis Anthony Giddens dan Karen Armstrong.

Menurut Giddens (The Constitution of Society, 1995), struktur dan tatanan masyarakat bukanlah sebuah entitas yang hadir begitu saja di luar kesadaran individu. Struktur dan tatanan muncul dan bekerja melalui tindakan pelaku, yaitu individu-individu dengan segenap pola pikir, kerangka penafsiran, persepsi, dan perspektif yang dihayati, dipraktekkan dan dipolakan. Tesis Giddens ini berimplikasi pada kesimpulan bahwa modus-modus kesadaran dan interaksi merupakan faktor primer, sedangkan struktur dan sistem sosial adalah faktor sekunder. Ini memang paradoks era teknostruktur. Ketika dunia kita semakin mampu dideskripsikan sebagai sebuan entitas jaringan melalui infrastruktur teknologi, ekonomi, dan lingkungan, potensi kreativitas pelaku dalam mengkonstitusi struktur dan tatanan juga kian tertantang dan tersingkap. Konsekuensi sosialnya adalah bahwa kesadaran, signifikansi (pemaknaan) dan proses mediasi menjadi faktor dominan dalam menata masyarakat.

Sementara itu, Karen Armstrong (The Battle for God: A History of Fundamentalism, 2001) menuturkan bahwa fundamentalisme radikal agama lahir di penghujung era modern sebagai sebuah respons irasional terhadap sekulerisme dan krisis spiritual dunia modern. Mereka dihadapkan pada situasi yang sulit mereka pahami bagaimana hidup yang bermakna sebagai seorang yang beriman dalam dunia modern yang sekuler atau bagaimana mengakomodasi tantangan-tantangan modern dalam horizon keimanan mereka. Bertali-temali dengan isu-isu sosial seperti kemiskinan, ketidakadilan global, marjinalisasi, perasaan terasing dari peradaban dunia (the other, mentalitas 'luar pagar') maka lahirlah paham fundamentalisme agama sebagai respons yang paling mudah dan instan. Buya Syafii Ma’arif menyebutnya sebagai ideologi sesat (Kompas, 12 Mare 2010).

Sinyalemen Armstrong itu menyumbang sebuah perspektif yang kerap luput dari pemahaman kita umumnya tentang gerakan fundamentalisme. Ideologi fundamentalisme tidaklah turun dari langit begitu saja atau lahir mencuat ke permukaaan dari kevakuman latar belakang sosial budaya. Ia adalah sebuah modus respons, yang Armstrong sebut sebagai sesuatu yang alamiah bagi setiap komunitas dalam memelihara identitas mereka. Karena itu, kita tidak mungkin bisa menghalangi siapapun di dunia ini memiliki pandangan dunia tertentu. Adalah mustahil melarang anak manusia untuk berpikir, bermimpi, dan bercita-cita. Selugu apapun seorang Amrozi, misalnya, tetaplah dia seorang manusia yang mempunyai visi dan pandangannya sendiri terhadap realitas termasuk tentang fakta ketidakadilan global. Tidak mungkin bisa kita melarangnya untuk berpikir dan memahami dunia dengan kepalanya sendiri.

Peluang yang mungkin dan terbuka bagi kita adalah menawarkan kerangka berpikir yang menempatkan Islam sebagai agama dan peradaban yang menjunjung tinggi nilai-nilai kemanusiaan universal. Untuk membuang karakter irasionalitas respons kaum radikal, kita perlu menyuguhkan 
strategi membangun mentalitas rasional. Saya tidak melihat ada strategi lain yang lebih menjanjikan dalam menumpas ekstrimisme dan jaringan terorisme hingga ke akar-akarnya kecuali melalui pengembangan kebudayaan dan tradisi yang menghargai akal sehat, pertimbangan nalar, kecakapan merenung, keterlatihan berpikir panjang, dan kepekaan nurani kemanusiaan universal. Melalui pembudayaan mental rasionalitas itulah, kita membangun fondasi yang di atasnya akan lahir secara alamiah (bukan hal yang dicangkokkan dari luar) sikap kritis, pola pikir terbuka, toleransi, dan perilaku yang proporsional dan penuh perhitungan.

Nah, sejalan dengan kian pentingnya dimensi kesadaran dan reflektif sebagaimana yang dikemukakan oleh Giddens di muka, strategi yang paling jitu adalah dengan mengungkap dimensi rasionalitas dan intelektualitas yang tumbuh dari doktrin Islam itu sendiri. Sejarah tradisi dan peradaban Islam yang panjang telah menggores betapa tingginya posisi akal, pikiran, nalar (berasal dari term al-Quran al-'aql, al-fiker, an-nadhara) dalam ajaran Islam. Sejumlah saintis dan filsuf besar telah dilahirkan dalam rahim peradaban Islam, katakanlah Ibn Sina (yang karyanya Qanun fi ath-Thib merupakan karya yang paling sering diterjemahkan ke dalam bahasa-bahasa Eropa pada era renaisans abad ke-13 hingga 17 M), Umar Khayyam (penyair-matematikawan peletak dasar geometri analitik), Ibn Rusyd (yang memantik api rasionalime di Eropa), atau kelompok Ikhwan ash-Shafa yang menyuarakan pesan-pesan universal kemanusiaan dan kosmopolitan.

Elaborasi kekayaan tradisi rasionalitas dari tubuh Islam itu sendiri juga bisa sekaligus menepis anggapan bahwa mentalitas rasional adalah sesuatu yang datang dan dicangkokkan dari luar, yang hanya akan melahirkan sikap reaktif sebagian umat Islam. Langkah inilah yang sebenarnya diusung oleh Cak Nur, yang semestinya kita lanjutkan melalui tindakan yang sistematis dan kontinyu, tidak lagi sekedar simbolik dan seremonial belaka. Artinya, sudah saatnya kita mengeksplorasi ajaran dan tradisi Islam yang memiliki pesan-pesan universal dan kosmopolitan. Dalam hal ini, filsafat dan sains merupakan dua tradisi ilmiah Islam yang amat kaya dengan doktrin-doktrin yang relevan dan berguna dalam pengembangan mentalitas rasional dan visi kemanusiaan universal.

\section{Manfaat Umum Studi Filsafat}

Tanpa basis kecakapan filosofis, agenda kebangkitan Islam melalui revitalisasi khasanah Islam hanya menjadi kajian sejarah masa lalu yang tak banyak membawa manfaat untuk umat zaman sekarang. Demikian pula, tanpa kemampuan berpikir yang kritis, otentik dan terbuka, penguasaan filsafat Islam secara tradisional tidak terlalu membawa faedah banyak karena akan impoten dalam mengaktualisasikan nilai-nilai yang dikandung filsafat Islam untuk konteks problema kehidupan manusia saat ini.

Oleh karena itu, kita perlu mengelaborasi secara kontekstual tentang perlunya dunia Islam menghidupkan kembali filsafat agar pembaca setidaknya dapat memahami mengapa studi filsafat dan khususnya filsafat Islam sangat penting dan mendesak kita lakukan khususnya di tanah air Indonesia. Selain sebagai pembentuk dasar pandangan dunia Islam yang mengisi ruh kebudayaan dan peradaban Islam sebagaimana panjang lebar telah dipaparkan sebelumnya, filsafat sebagai sebuah metode berpikir dalam menganalisis persoalan secara radikal (mengakar, mendasar) dan menyeluruh juga turut berperan penting dalam membentuk pola pikir dan perilaku keseharian kita baik sebagai individu maupun warga masyarakat.

Agaknya tidak berlebihan jika dikatakan bahwa sudah cukup lama umat Islam di Indonesia terjebak ke dalam pola pikir pragmatis, legalistik, dan product oriented yang selalu mengukur manfaat suatu wacana dan aktivitas dari nilai guna seketika (instantly), formalitas yang tertera secara verbal linguistik, dan kasat mata yang dapat dihitung dengan angka. Dalam pemilu legislatif dan presiden 
atau gubernur misalnya, umat kita mudah sekali dibujuk oleh sesuatu yang bermanfaat dalam jangka pendek, katakanlah uang dan sembako, tetapi melupakan efek jangka panjangnya kepada bangsa dan diri mereka sendiri. Praktek money politics tentu saja akan melahirkan pemimpin-pemimpin yang culas dan tak bertanggugjawab kepada bangsa karena mereka harus mengejar 'setoran' membayar kembali biaya kampanyenya hingga ratusan milyar rupiah. Pola pikir seperti inilah yang menjerumuskan kita untuk selalu bertindak kasuistik (ad hoc), yaitu tindakan-tindakan yang merupakan respons parsial terhadap situasi sesaat sehingga cenderung bersifat atomistik, terpisah-pisah (segregated), dan reaktif.

Paradigma berpikir yang tertawan oleh situasi kekinian dan kesinian ini (spasio temporal) justru bertentangan dengan keunggulan manusia sebagai mahkluk transendental, yakni kemampuan kreatif dan nalar insani untuk mampu melampaui batasan-batasan spasio temporal. Menurut Nurcholish Madjid, krisis bangsa yang kita alami sekarang ini tidak terlepas dari kesalahan kebijakan kita di masa lalu, yaitu memprioritaskan pembangunan ekonomi, tetapi mengabaikan pengembangan sumber daya manusia. Cak Nur, sapaan akrab alamarhum Nurcholish Madjid, mengatakan sekiranya sejak dulu kita menomorsatukan pendidikan ketimbang ekonomi, mungkin krisis kita tidak separah seperti sekarang-dia seraya mencontohkan Korea Selatan yang cepat bangkit dari krisis karena tingkat pendidikan masyarakatnya yang relatif lebih tinggi.

\section{Filsafat sebagai Mata Kunci}

Mungkin di luar dugaan perkiraan banyak orang jika disebutkan bahwa filsafat dapat berguna membantu penyelesaian problem-problem konkret seperti sosial politik, penegakan supremasi hukum, pengentasan kebodohan dan kemiskinan, dan sebagainya. Berbagai krisis yang tengah kita hadapi sekarang (krisis-krisis ekonomi, politik, kepemimpinan, disintegrasi, moral, kepercayaan, budaya, lingkungan, dan sebagainya), jika tidak dikatakan bermula dari, setidaknya, berkorelasi erat dengan krisis persepsiyang terjadi di benak kita baik sebagai individu maupun sebagai anggota masyarakat yang masing-masing telah memiliki kesadaran/memori kolektif (collective memory).

Salah satu bentuk krisis persepsi yang kerap terjadi adalah ketidakmampuan kita menangkap substansi suatu persoalan, termasuk hal ihwal persoalan kebangsaan kita hari ini. Betapa banyak perdebatan-perdebatan ilmiah, terlebih lagi yang populer seperti yang dipertontonkan oleh media elektronik, hanya mengupas permukaan persoalan. Pembahasan dan diskusi yang terjadi kerap bersifat superfisial (dangkal), atomistik, terpilah-pilah, monokausal, dan simplistik (terlalu menyederhanakan). Perdebatan wacana tentang isu-isu seperti demokrasi, hak asasi manusia, gender, pluralisme, dan sebagainya tidak jarang malah kontraproduktif lantaran tidak tergalinya muatan-muatan filosofis yang menjadi asumsi dasar dari isu-isu tersebut, demokrasi, misalnya.

Sebagai contoh, jika kita memperhatikan saksama perdebatan politik antara eksekutif dengan legislatif, hal itu kentara sekali mementaskan bahwa para petinggi politik kita lebih disibukkan oleh soal-soal yang berkaitan dengan perasaan, emosi, dan harga diri. Perang statement antara petinggi politik kita lebih merepresentasikan ledakan emosi dan respons ketersinggungan perasaan pribadi mereka daripada sebagai debat wacana yang memasuki substansi persoalan. Pernyataan-pernyataan yang mereka lontarkan cenderung provokatif, sentimental, dan kerap bernuansa "sakit hati dan balas dendam secara personal/kelompok"; dan sebaliknya, mereka sangat jarang mengemukakan argumentasi-argumentasi yang dapat diverifikasi secara rasional dan kewarasan nalar publik. Praksis politik negara kita masih primitif karena menganggap kekuasaan politik formal menjelmakan kekuasaan negara itu sendiri, bukan sebagai pentas bagaimana mengelola negara ini secara dewasa, rasional, dan beradab. 
Sudah saatnya para pengambil kebijakan negara, termasuk kaum intelektual bangsa, mempelajari logika, etika, filsafat manusia, filsafat politik, dan hal senada lainnya. Keterlatihan berpikir filosofis yang rasional, kritis, refleksif, radikal (mendasar, mendalam), sistematis, dan menyeluruh secara epistemologis akan mengonstruksi pemikiran dan mental kita untuk lebih rendah hati, bijak, rasional (tidak sentimental), transparan, dan membuka ruang dalam diri untuk siap dikritik dan berdiskusi secara argumentatif.

Sebuah penerapan praktis dari epistemologi untuk pendekatan ilmu-ilmu sosial telah digunakan sejak 1990-an, yaitu apa yang disebut sebagai analisis wacana (discourse analysis). Analisis wacana ini menyoroti bagaimana suatu perspektif dapat terbentuk pada diri seseorang atau sekelompok orang dalam memersepsi realitas. Analisis ini meneliti, mendiskusikan, dan menguji kesahihan dan akuntabilitas keputusan-keputusan atau tindakan-tindakan politik yang dilakukan oleh seseorang atau sekelompok orang dengan mengacu kepada prinsip-prinsip politik, baik pada tingkat empiris (matter of fact) maupun pada tingkat normatif (matter of principle). Dengan demikian, setiap keputusan politik dapat diverifikasi dan dipertanggungjawabkan secara transparan. Walhasil, boleh dikatakan studi filsafat dapat berperan mengasah dan mempertajam penalaran kita, dan juga membongkar kejumudan pola pikir yang kita warisi begitu saja yang seakan turun dari langit (taken for granted). Filsafat ibarat obat mujarab bagi krisis persepsi yang berkorelasi erat dengan problem-problem konkret. Filsafat bagaikan mata kunci yang membuka hijab-hijab formalisme dan irasionalisme untuk menembus dan menangkap substansi persoalan.

\section{Antisipasi Krisis Modernisme}

Evolusi ilmu pengetahuan dan kebudayaan manusia telah sampai kepada zaman yang memaksa kita untuk berpikir holistik, sistemik dan refleksif-mendalam dalam memahami realitas. Berpikir holistik maksudnya adalah suatu bentuk kognisi yang memahami realitas sebagai suatu sistem keseluruhan yang utuh. Tak seperti berpikir parsial yang memulai dari bagian untuk memahami keseluruhan, berpikir holistik memulainya dari pemahaman keseluruhan sebelum memasuki bagian-bagiannya. Persoalan pemanasan global (global warming), misalnya, harus dipandang sebagai suatu fakta keseluruhan menyangkut atmosfir bumi kita, yang tidak bisa ditangani parsial oleh beberapa negara. Karena itu, penyelesaiannya harus ditangani bersama yang menuntut keutuhan dalam sikap dan bertindak. Efek pemanasan global hanyalah salah satu isu penting dalam apa yang disebut sebagai krisis ekologis. Krisis yang hangat dibicarakan sekarang ini sesungguhnya telah mengentakkan kesadaran manusia modern untuk menggugat pandangan kosmologi modern yang positivistikantroposentris yang mereka anut hampir tiga abad. Krisis ini menggugah seorang filsuf analitik dari Norwegia, Arne Naess, yang melakukan hijrah intelektual untuk menjadi pelopor apa yang disebut sebagai Gerakan Ekologi Dalam (Deep Ecology Movement) pada pertengahan 1970-an.

Perkembangan ilmu pengetahuan dan teknologi yang sedemikian pesat dan telah mengarah kepada ancaman eksistensi dan kemuliaan martabat manusia juga mendorong kaum pemikir dan cendekiawan untuk menoleh kembali etika dan moral. Perkembangan bioteknologi semisal kemungkinan praktek pengklonan manusia, misalnya, mendorong ilmuwan, filsuf dan agamawan merumuskan prinsip-prinsip dan kaidah-kaidah bioetika. Pada saat yang sama, pada tataran internal ilmiah, kemajuan revolusioner sains secara tak terduga merubuhkan positivisme sebagai paradigma standar epistemologi modern. Banyak ilmuwan yang tiba-tiba beralih menjadi filsuf. Fisikawan Thomas Kuhn, misalnya, mencoba memahami gerak laju ilmu pengetahuan-yang menurutnya diskontinu - dengan mengembangkan konsep "paradigma" sains yang berkorelasi erat dengan metafisika dan 
nilai (The Structure of Scientific Revolutions). Fritjof Capra, bahkan, terpaksa menoleh hikmah Timur, khususnya Taoisme, untuk membingkai kembali bangunan ilmu pengetahuan dari puing-puing relativisme dan skeptisisme (The Tao of Physics). Tampaknya, sejarah telah menuntut kita bahwa perkembangan ilmu pengetahuan tidak boleh melupakan induknya, yakni filsafat.

Namun, krisis modernisme tidak berhenti pada krisis epistemologis dan ekologis saja. Krisis yang lebih akut lagi adalah krisis-krisis eksistensial yang menyangkut hakikat dan makna kehidupan itu sendiri. Manusia modern mengalami kehampaan spiritual, krisis makna dan legitimasi hidup, kehilangan visi untuk apa hidup, dan keterasingan (alienasi) terhadap dirinya sendiri. Menurut Syed Hossein Nasr, dalam The Plight of Modern Man (London, 1976), krisis-krisis eksistensial ini bermula dari pemberontakan manusia modern kepada Allah. Mereka telah kehilangan harapan terhadap kebahagiaan masa depan seperti yang dijanjikan oleh Renaisans, Abad Pencerahan, sekularisme, sains, dan teknologi. Di sinilah peran kedua kajian filsafat khususnya filsafat Islam, yaitu mendekonstruksi paradigma modernisme yang telah memberhalakan materialisme, ateisme, dan sekularisme.

\section{Rekonstruksi Filsafat Pasca-Modernisme}

Peran ketiga filsafat saat ini adalah melanjutkan semacam proyek dekonstruksi, yaitu merekonstruksi filsafat yang dapat memberi jalan keluar dari kebuntuan (deadlock) filsafat Barat modern dan krisis-krisis eksistensial manusia modern. Dalam momen ini, filsafat Islam dapat mengambil peran penting untuk memberikan kontribusi bagi proyek "penyelamatan" peradaban manusia di masa depan. Salah satu manifestasi Islam sebagai rậâtan lil âlamîn, dalam hal ini secara filosofis, adalah menawarkan pandangandunia yang utuh, holistik, dan penuh makna kepada manusia modern dalam mempersepsi realitas.

Khazanah filsafat Islam klasik dan kontemporer sesungguhnya sangat kaya. Sayangnya, sampai sekarang kekayaan intelektual itu masih tersimpan dalam perpustakaan-perpustakaan Islam dan Barat, belum banyak digali. Pemikiran filsuf jenius Ibn Sînâ, misalnya, masih banyak yang belum terungkap, terutama perkembangan akhir pemikirannya seperti pada karya-karya Isyârât wa Tanbîhât, al-Manthiq al-Masyriqiyyah (Logika Timur). Belum banyak orang tahu bagaimana Ibn Sînâ memecahkan persoalanpersoalan ilmiah dan filosofis juga menggunakan metode iluminasionis melalui renungan dan shalat, jauh sebelum Quantum Learning itu heboh.

Mungkin akan lebih terasa asing bagi kebanyakan manusia modern jika disebutkan bahwa Suhrawardî mencetuskan aliran filsafat isyrâqiyyah (Pencerahan) atau menyebutkan bahwa pemikiran Mullâ Shadrâ menjadi semacam puncak perkembangan filsafat Islam pada abad ke-17, sezaman dengan Bapak Filsafat Modern René Descartes. Sebagai perbandingan saja, seorang filsuf Prancis Henry Corbin yang sejak muda berminat mencari filsafat yang serius-mendalam, suatu kali pernah menyebut, "filsafat eksistensialis Heidegger sebagai catatan kaki bagi filsafat eksistensialis (Falsafah Wujûd) Mullâ Shadrâ". Padahal, Heidegger adalah seorang filsuf Jerman yang dikenal sebagai tokoh eksistensialis terkemuka Barat sampai saat ini.

Kekhasan cara berpikir filsafat Islam adalah pandangannya yang utuh dan terpadu terhadap kajian metafisika, epistemologi, etika, kosmologi, dan psikologi. Hal itu merupakan manifestasi nilai Tauhid.Pemahaman yang benar tentang eksistensi/wujud (metafisika) akan berimplikasi kepada pemahaman yang tepat tentang pengetahuan (yaitu sebagai modus eksistensi), dan pada gilirannya berimplikasi pada pemahaman yang eksistensial tentang nilai-nilai moral. Bermula dari refleksi mendalam terhadap makna Wujud, filsafat wujud atau filsafat eksistensialis Islam berbeda dengan eksistensialisme Barat, karena memiliki landasan metafisika yang kukuh, epistemologi realis-konstruktif, 
dan bersifat teleologis. Sifat-sifat seperti inilah yang diharapkan dapat memperolehkembali pegangan hidup bagi manusia modern, selain hal itu turut dapat memuasi tuntutanintelektual manusia modern guna mengobati krisis-krisis eksistensial modernitas.

Jika Islam memang diharapkan mampu memberikan kontribusi dalam pengembangan sistemsistem alternatif di berbagai bidang kehidupan, maka semuanya itu hanya mungkin terwujud dengan baik dan genuine (orisinal, otentik) bila terlebih dahulu dibangun fondasi filosofis sedemikian. Oleh karena itu, bukan merupakan suatu hal yang kontroversial jika mengatakan bahwa berbagai sistem kehidupan itu -entah ekonomi, politik, sosial, budaya, apalagi keagamaan - tak pernah bisa dilepaskan dari persoalan-persoalan filosofis yang menjadi fondasinya. Termasuk di dalamnya, maknasejati kemanusiaan, keadilan, persamaan, kesejahteraan, dan kebahagiaan sebagai tujuan semua solusi.

\section{Filsafat sebagai Pendewasaan Umat}

Salah satu sumber keprihatinan kita terhadap kondisi psikososial kita (umat Islam) sekarang adalah kelambatan kita untuk bisa keluar dari "masa kanak-kanak" dalam banyak hal. Hal ini ditandai dengan ciri-ciri sebagai berikut: terobsesinya umat dengan simbol-simbol formalisme-legalistik, pemahaman keagamaan yang superfisial dan skripturalistik, mudahnya kita terpesona dengan retorika dan orasi emosional yang sering kurang penalaran, dan pada saat yang sama, gamang menghadapi tantangan realitas zaman yang menuntut kemampuan apropriasi, yaitu kemampuan memahami orang lain tanpa terlebur ke dalamnya tapi justru memperkaya pemahaman tentang diri sendiri.

Sikap penentangan membabi buta terhadap teori evolusi misalnya, telah menghabiskan energi dan dana umat yang sangat banyak, padahal ternyata teori itu tidak harus dikaitkan dengan Darwinisme atau ateisme. Ini hanya persoalan bagaimana kita menafsirkan temuan-temuan ilmiah dalam perkembangan spesies secara benar dan dalam hal ini, filsafat Islam bisa menawarkan jalan keluar penyelesaian antara konsep evolusi dengan prinsip Tauhid. Ulama-filsuf Muthahhari pernah membahas relasi teori evolusi dengan pandangan-dunia Tauhid (baca bukunya Rub dan Materi, Yayasan Muthahhari, Bandung, 1991).

Kita, biasanya, mengambil jalan pintas nan mudah, yakni menutup diri dari ideologi-ideologi/ ajaran-ajaran asing seraya mencap mereka sesat dan berbahaya. Padahal, dalam zaman yang semakin plural dan kompleks seperti sekarang ini, kemampuan apropriasi seperti itu merupakan kebutuhan yang tidak bisa ditawar-tawar lagi.

Di sinilah peran keempat filsafat, yaitu membuka wawasan berpikir umat untuk menyadari fenomena perkembangan wacana keagamaan kontemporer yang menyuarakan nilai-nilai keterbukaan, pluralitas, dan inklusivitas. Studi filsafat sebagai pilar utama rekonstruksi pemikiran dapat membongkar formalisme agama dan kekakuan pemahaman agama-atau dalam istilah M. Arkoun sebagai taqdîs al afkâr al-diniyyah (penyakralan pemikiran keagamaan) - sebagai salah satu sumber eksklusivisme agama dan kejumudan umat. Salah satu problem krusial pemikiran dan pemahaman keagamaan sekarang ini, misalnya, adalah perumusan pemahaman agama yang dapat mengintegrasikan secara utuh visi ilahi dan visi manusiawi tanpa dikotomi sedikitpun.

Karena itu, kembali kepada diagnosa al-Afghâni, gerakan pembaharuan Islam harus menampilkan Islam sebagai suatu peradaban dan pandangandunia yang utuh dan menyeluruh. Gerakan pembaharuan Islam harus dapat mengelaborasi pandangandunia Islam ke dalam berbagai bidang kehidupan. Elaborasi ini merupakan proses terus menerus untuk mentranformasi fakta-fakta menjadi nilai-nilai, aksi-aksi menjadi tujuan-tujuan, dan harapan-harapan menjadi kenyataan-kenyataan. Proses elaborasi ini tak syak lagi membutuhkan kajian epistemologi Islam, hal yang merupakan salah satu 
tema sentral dalam filsafat Islam. Dengan demikian, kajian filsafat merupakan keniscayaan bagi para pemerhati dan pelaku upaya rekonstruksi peradaban Islam.

Oleh karena itu, untuk mengentaskan masa kanak-kanak (mendewasakan) umat Islam, mungkin sudah saatnya filsafat harus dianggap sebagai anak sah dari peradaban Islam, bukan lagi anak haram sebagaimana yang dipahami oleh kaum ortodoks seperti kaum salafi, Wahabi atau Asy'ariyyin. Sikap seperti itu mengandaikan bahwa seseorang tidak mengenal sejarah keemasan peradaban Islam.

\section{Filsafat dan Revolusi Mental untuk Strategi Kebudayaan Islam}

Uraian di muka membawa kita kepada kesadaran tentang pentingnya suprasistem nilai budaya sebagai basis pengembangan sistem-sistem ekonomi, politik, hukum, pendidikan, dan iptek yang bermuatan nilai-nilai Islam. Suprasistem adalah sistem nilai budaya primer yang melandasi segenap sistem sosial sebuah kebudayaan dan peradaban. Dalam istilah sejarawan antropolog Fernand Braudel, suprasistem itu disebut sebagai 'mentalite', sebuah struktur/lapisan kesadaran terdalam sebuah masyarakat (A History of Civilizations, Penguin Books, London, 2001). Sedang kebudayaan itu sendiri disebut Clifford Geertz sebagai sistem simbolik signifikansi, yaitu "pola-pola makna yang melekat dalam simbol-simbol yang diwariskan secara historis yang dengannya manusia mengkomunikasikan, melestarikan dan mengembangkan pengetahuan dan sikap terhadap hidup" (Geertz, The interpretation of Cultures, Basic Book, New York, 1973. hal. 89).

Mengacu kepada tiga wilayah/struktur kebudayaan yang dirumuskan oleh Koentjaraningrat (Ilmu Antropologi, Aksara Baru, Jakarta, 1985), suprasistem adalah sistem ideofak yang terdapat pada lingkaran paling dalam wilayah kebudayaan.

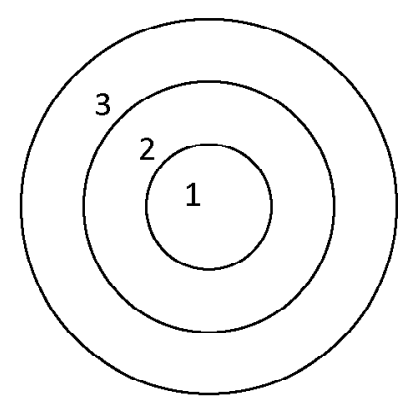

1. ideofak : sistem gagasan, nilai, asumsi-asumsi dasar

2. sosiofak: sistem sosial, perilaku, kebahasaan (ekspresi ide)

3. artefak: bentuk material

Tanpa latar belakang kesadaran budaya dan pandanganduniaIslam yang kukuh sebagai ideofak (sistem gagasan), strategi kebudayaan dan program Islamisasi apa pun akan menemui kebuntuan. Nilai-nilai Islam bukanlah sebuah produk manufaktur yang instan sehingga dapat diamalkan begitu saja tanpa basis diskursus intelektual-epistemologis yang matang.

Sebagai contoh, program Islamisasi ilmu pengetahuan yang dikumandangkan sesuai Konferensi Dunia Pertama tentang Pendidikan Islam pada 1977, sampai kini belum berjalan seperti yang diharapkan. Konsep Islamisasi sains yang ditawarkan Isma'il Raji al-Faruqi dengan mensintesiskan ilmu-ilmu tradisional Islam ke dalam buku-buku daras sains modern mendapat kritikan tajam dari sarjana Muslim sendiri. Hal yang dilakukan al-Faruqi tidak lebih sekadar mencangkokkan kepingankepingan ilmu Islam ke dalam kultur organis sains modern, tanpa menawarkan paradigma sains baru yang Islami. Paradigma positivisme yang merupakan fondasi sains (epistemologi) Barat modern sama 
sekali tidak digubris, padahal pokok persoalan Islamisasi sains justru terletak pada bagaimana kita memanfaatkan sains sebagai salah satu unsur dalam stuktur pengetahuan Islam untuk menyingkap realitas yang berdimensi ilahiah.

Dengan demikian, program Islamisasi sains tidak akan berjalan tanpa didahului pengkajian epistemologi (filsafat pengetahuan) Islam. Studi epistemologi Islam pada gilirannya juga menuntut studi ontologi-metafisika Islam, yaitu pandangan Islam ihwal realitas dari prinsip-prinsip kemaujudan. Oleh karena itu, Munawar A. Anees menyambut gembira usaha Seyyed Hossein Nasr yang memperkenalkan citra baru sains Islam yang ditopang dengan elaborasi khazanah filsafat Islam klasik. Nasr, dalam bukunya Man and Nature: The Spiritual Crisis of Modern Man (Chicago, 1997) berhasil menelanjangi argumen-argumen yang memandang sains Barat modern sebagai bebas nilai. Sains modern seperti ilmu pengetahuan alam, ilmu pengetahuan sosial, terlebih ilmu-ilmu humaniora, ternyata sarat dengan bias ideologi dan nilai Barat.

Urgensi menghidupkan kembali filsafat Islam kian terasa jika disadari bahwa pelbagai nilai materialisme, agnostisisme, pragmatisme, dan positivisme peradaban Barat telah menggurita dalam struktur kehidupan modern. Nilai-nilai yang mengikis fitrah kita sebagai manusia banîf (gandrung kepada kebenaran) itu, bukan saja telah memasuki ruang personal kita—seperti kamar tidur-melalui TV, internet, ruang-ruang kelas, perkantoran, pasar, kampus, dan masjid, tetapi juga telah membentuk pola pikir dan sikap mental kita sehari-hari. Kebiasaan menonton film action tentang kehebatan kekuatan fisik dan militer, misalnya, akan membangun mentalitas yang mengutamakan kekuasaan fisik (hardpower) dalam menyelesaikan setiap persoalan. Fenomena ini mungkin bisa dijelaskan dengan bantuan teori "praktek" (practice) yang dikemukakan oleh Piere Bourdieu. Menurut Bourdieu, manusia sebagai agen juga turut mengkonstruksi simbol dan nilai budaya yang dia adopsi melalui interaksi dengan kondisi sosial sebagai wahana cara dia berada (babitus).

Nilai-nilai asing yang meracuni Tauhid dan fitrah kemanusiaan kita memang subtil (halus), hal yang mengingatkan kita pada sabda Nabi Saw. bahwa "Kemusyrikan itu halus dan tidak tampak, bagaikan semut hitam berjalan di atas batu pada kegelapan malam". Jika kita mengatakan bahwa hanya orang yang memiliki pandangan Tauhid mendalam yang dapat melihat kemusyrikan itu, maka kita bisa pula mengatakan bahwa hanya orang yang memahami filsafat Islam dan Barat yang dapat melihat penjajahan mental kaum Muslim oleh nilai-nilai Barat.

Sebuah contoh yang menunjukkan keterjajahan kaum Muslim secara mental pikiran adalah keberhasilan Barat menanamkan pandangan bahwa semua negara Barat adalah Dunia Pertama (negara maju), sedangkan negara-negara Islam adalah Dunia Ketiga (negara berkembang). Penggunaan istilah "Dunia Ketiga" mengesankan bahwa kita hanyalah ibarat penumpang dalam kapal yang dinahkodai Barat. Dunia ini milik Barat, kita harus ikut bersamanya jika ingin selamat mengarungi lautan dunia. Semua negara Barat adalah negara maju yang menjadi model, standard, dan referensi kita dalam segala tujuan ekonomi, demokrasi, pendidikan, iptek, dan peradaban. Oleh karena itu, pembangunan negara kita, yang dikategorikan sebagai negara berkembang, harus mengacu pada segala ukuran, kriteria, dan indikator yang diterapkan Barat melalui lembaga-lembaga internasional yang mereka bentuk, seperti IMF, Bank Dunia, W'TO, Amnesti International, dan sebagainya.

Pada akhirnya, pranata sosial, ekonomi, politik, dan hukum negara kita terpaksa dikonstruksi sedemikian rupa agar sesuai dengan struktur pranata induk semang Barat. Oleh sebab itulah, nasib ekonomi kita, misalnya, menjadi sangat bergantung pada pasar internasional kapitalistik yang setiap saat membutuhkan tumbal agar roda ekonomi dunia berjalan. Krisis moneter dan ekonomi yang kita alami hampir satu dekade merupakan sebuah contoh betapa lembaran-lembaran kertas dolar dapat 
mengobrak-abrik perekonomian dan menguras kekayaan alam kita. Betapa berkuasanya sistem perekonomian dunia kapitalistik sehingga dapat mengendalikan harga barang-barang negara "Dunia Ketiga" hanya melalui permainan valuta asing.

Pada saat yang sama, miliaran dolar kekayaan negeri kita mengalir deras ke Amerika Serikat dan Eropa melalui royalti berbagai produk mereka, seperti merek barang/jasa, periklanan, film, musik, dunia hiburan, dan produk budaya Barat lainnya yang diimpor. Penjajahan ekonomi ini bersumber dari penjajahan budaya, penjajahan mental pikiran, penjajahan pandangan hidup, di samping kejumudan dan terpasungnya daya nalar dan kreatif umat Islam itu sendiri secara internal.

\section{Menegok Tujuh Tradisi Keilmuan Islam}

Kekayaan khazanah Islam klasik yang merupakan konstitusi peradaban Islam itu dapat dilihat pada tradisi keilmuan yang diwariskan kepada kita. Terdapat tujuh (7) tradisi keilmuan yang patut kita apresiasi dan kembangkan dalam konteks kekinian sebagai bagian proyek rekonstruksi peradaban Islam yang tengah kita rancang dengan menerapkan beberapa pendekatan modern seperti fenomenologi, telaah kritis, telaah historis, dan hermeneutik.

Ketujuh tradisi keilmuan Islam itu adalah : (1) Ilmu-ilmu al-Qur'ân; (2) Ilmu-ilmu hadis; (3)

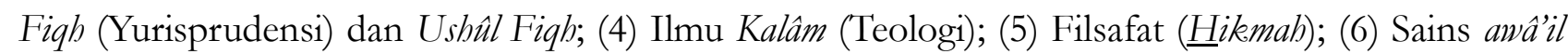
(sains umum yang diwariskan oleh peradaban-peradaban pra-Islam seperti astronomi, alkimia, fisika, kedokteran, geometri); dan (7) Tasawuf ('Irfân, Gnosis). ${ }^{2}$ Dua tradisi keilmuan yang pertama berkaitan dengan upaya elaborasi pemahaman terhadap sumber ajaran Islam: al-Qur'ân dan Sunnah. Lima tradisi keilmuan selanjutnya merupakan kegiatan kreatif keilmuan para sarjana Muslim untuk mengungkapkan kebenaran-kebenaran Islam berdasarkan telaah pokok bahasan atau kawasan objek telaah dan metodologi yang digunakan.

Ilmu-ilmu al-Qur'an ('Ulum al-Qur'an) merupakan sebuah rumpun ilmu-ilmu yang terkait dengan usaha kaum Muslim untuk memahami pesan-pesan Tuhan yang termaktub dalam Kitab Suci al-Qur'an. Di samping menjadi sumber utama segala corak pemikiran Islam seperti yang telah diuraikan secara ringkas pada Bab Empat, al-Qur'an juga telah mendorong kaum Muslim untuk menelaah dan mengembangkan metodologi bagaimana memahami dan menafsirkan ayat-ayat al-Qur'an sebagaimana yang dititahkan Allah swt dan diajarkan oleh pembawanya, Nabi Suci Muhammad saw. Dilihat dari perspektif filsafat ilmu, pengembangan metodologi merupakan sebuah bentuk pertanggungjawaban ilmiah dalam suatu disiplin ilmu; dan tradisi ini cukup kuat dalam ilmu tafsir dan ta'wil al-Qur'an. Dalam konteks inilah, kita harus mengerti mengapa Nabi saw melarang membuat penafsiran alQur'an berdasarkan pendapat sendiri tanpa penguasaan ilmu dan metode yang memadai karena hal itu tidak dapat dapat dipertanggungjawabkan secara keilmuan.

Ilmu-ilmu hadis ('Ulum al-hadits) merupakan rumpun ilmu-ilmu yang lahir dari kebutuhan kaum Muslim untuk memperoleh hadis dan sunnah Nabi saw yang otentik dan sahih. Mengingat pentingnya hadis sebagai bayan (penjelas, pemberi keterangan) al-Qur'an dan juga sebagai sumber hukum Islam kedua sesudah al-Qur'an, maka studi ilmu hadis menempati posisi yang penting dalam ilmu-ilmu tradisional Islam. Karena tujuan pokok ilmu hadis adalah menguji kesahihan hadis yang begitu banyak

${ }^{2}$ Penyebutan tujuh kategori tradisi keilmuan Islam ini bersandar pada sejumlah referensi, seperti karya Taufik Abdullah (ed.), Ensiklopedi Tematis Dunia Islam Jilid 4 tentang Pemikiran dan Peradaban (Jakarta: PT Ichtiar Baru Van Hoeve, 2002), Murtadha Muthahhari, Understanding Islamic Sciences (London: ICAS Press, 2002), dan Seyyed Hossein Nasr, Islamic Life and Thought (London: George Allen \& Unwin, 1981), Seyyed Hossein Nasr, Traditional Islam in the Modern World (London: Kegan Paun International, 1987). 
bertebaran di kalangan sahabat dan tabïn (generasi sesusah sahabat) maka lahirlah beragam metode dan cara verifikasi yang melahirkan cabang-cabang ilmu seperti ilmu riwayah (studi periwayatan dan pengutipan hadis), ilmu dirayah (pembahasan penerimaan dan penolakan hadis dari segi sanad dan matan), ilmu rijal al-hadits (studi perawi hadis), dan ilmu jarh wa ta'dil (studi tentang cacat moral dan adilnya perawi hadis). Yang menarik adalah adanya studi tentang karakter perawi hadis ini menggambarkan pentingnya moralitas para pelaku yang meriwayatkan sejarah.

Fiqh (fikih) dan ushul figh (usul fikih) merupakan cabang-cabang ilmu tradisional Islam yang terkait dengan upaya memahami hukum Islam yang termaktub dalam al-Qur'an dan sunnah Nabi saw. Jika fikih adalah studi yurisprudensi (istinbat) bagaimana memahami, menggali, dan menetapkan hukum dari sumber-sumbernya (al-Qur'an dan sunnah Nabi SAW), maka usul fikih adalah studi tentang prinsip-prinsip yurisprudensi itu sendiri. Salah satu prinsip yurisprudensi yang disepakati oleh mazah-mazhab Islam adalah empat sumber hukum Islam, yaitu al-Qur'an, Sunnah Nabi saw., ijma', dan akal (dengan catatan terdapat perbedaan pendapat pengertian ijma' antara mazhab Syi'ah dan Sunni, yang tak relevan dibahas di sini). ${ }^{3}$

Ilmu kalam (teologi) adalah studi tentang prinsip-prinsip dasar keimanan Islam (ushuluddin) meliputi keyakinan keesaan Allah (tawhid), kenabian (nubuwwah) dan hari kebangkitan (qiyamah). Ketika membahas ilmu Tauhid muncul kajian tentang dzat Allah (tawbid al-dzati), sifat-sifat Allah (tawhid alsifati), tindakan dan kebijaksanaan Allah (tawhid al-af'ali), dan bagaimana seorang mukmin seharusnya beribadah hanya karena dan untuk Allah (tawhid al-'ibadi). Termasuk ke dalam persoalan pokok teologis adalah menyangkut keadilan Tuhan (al-'adl ilahi), takdir, kehendak bebas manusia, penciptaan dunia, dan khususnya bagi mazhab Syi'ah tentang Imamah (kepemimpinan penerus kenabian). Isu-isu ini tentu saja melibatkan penggunaan akal dalam usaha menjawab dan menjelaskannya. Namun, penggunaan akal dalam teologi tidaklah seperti yang diterapkan dalam filsafat dan logika, karena ia juga menggunakan rujukan teks wahyu dan hadis (dalil naqli) dalam berargumentasi. Itulah sebabnya mengapa ilmu kalam menggunakan metode dialektis (jadal) dalam berargumen, karena para teolog berusaha membuktikan premis-premis tertentu dengan merujuk pada teks-teks al-Qur'an dan hadis sebagai premis (keyakinan) dasar. Adalah Nashiruddin al-Thusi (1201-1274) yang mencoba menerapkan metode demonstrasi (burban) sepenuhnya -seperti dalam filsafat- dalam mengupas persoakan-persoalan teologis. Dalam era kontemporer, Murtadha Muthahhari (1919-1979) dalam karyanya Keadilan Ilahi menggunakan pendekatan filosofis dan metode demonstratif dalam menbedah persoalan teologis yang selalu aktual dengan kehidupan kemanusiaan ini. ${ }^{4}$

Filsafat -sebagaimana logika - merupakan ilmu Islam rasional yang telah melahirkan para pemikir-filsuf yang disegani di dunia seperti al-Farabi, Ibn Sina, kelompok Ikhwan Shafa, Ibn Rusyd, Suhrawardi, Mulla Shadra hingga zaman kontemporer seperti Muhammad Iqbal, Allamah Tabataba'i, Seyyed Hossein Nasr, dan Mehdi Ha'iri Yazdi. Muthahhari menyebut filsafat sebagai anak kandung peradaban Islam yang telah memberi kontribusi besar dalam membangun fundasi keyakinan kaum Muslim yang kokoh dan turut mendorong mentalitas rasional dan semangat ilmiah dalam dunia Islam. Dalam bukunya Understanding Islamic Sciences (2002), Muthahhari menjelaskan bahwa term falsafah dan hikmah yang digunakan filsuf Muslim bermakna sebagai pengetahuan rasional umum, yang diperlawankan dengan ilmu-ilmu konvensional seperti bahasa, etimologi, sintaksis atau ilmu-ilmu

${ }^{3}$ Perbedaan tersebut diuraikan secara ringkas oleh Murtadha Muthahhari dalam karyanya Understanding Islamic Science (London: ICAS Press, 2002), h. 184-185

${ }^{4}$ Karya ini telah diterbitkan oleh Penerbit Mizan dalam dua edisi (edisi kedua diterbitkan pada tahun 2009, Bandung) 
yang yang ditransmisikan seperti ilmu hadis, fikih, dan tafsir al-Qur'an. Dalam pengertian umum ini, filsafat adalah sebuah penyempurnaan jiwa manusia baik secara teoritis maupun praktis. Sedangkan dalam pengertian khusus, yaitu apa yang disebut dengan 'filsafat pertama', atau metafisika, ia adalah sebuah disiplin ilmu yang menelaah prinsip-prinsip umum keberadaan maujud sebagai maujud. Sementara itu Seyyed Hossein Nasr dalam esainya "The Qur'an and Hadith as Source and Inspiration of Islamic philosophy" menyebutkan bahwa penggunaan term al-haqiqah dalam filsafat Islam dan al-Qur'an merupakan petunjuk kuat eratnya hubungan di antara mereka. Al-haqiqah berarti dua hal sekaligus: kebenaran dan realitas. Al-Haqq juga adalah salah satu nama Tuhan. Apa yang digarisbawahi Nasr ini merupakan bagian dari kajian apa yang disebut dalam filsafat ilmu sebagai context of discovery, yakni pembahasan mengenai latar sosio-kultural sebagai konteks perkembangan sebuah disiplin ilmu.

Sains awa'il adalah nama rumpun ilmu-ilmu yang diperoleh dari peradaban-peradaban kuno pra-Islam seperti geometri, kedokteran, astronomi, fisika, dan kimia. Filsafat yang datang dari peradaban Hellenisme, karena sifatnya yang khas menggunakan akal murni, dikategorikan tersendiri. Mengenai sikap kaum Muslim terhadap sains awa'il ini, menarik untuk menyimak kisah bagaimana Imam Ali kw. yang merupakan sahabat alim Nabi, gurunya para guru ilmu-ilmu tradisional Islam, dan mendapat julukan tajul 'arifin (mahkota orang-orang bijak) turut menyelesaikan persoalan fisika khususnya penerapan hukum Archimedes untuk menimbang sesuatu. ${ }^{6} \mathrm{Nabi}$ Suci saw. sendiri menyuruh kaum Muslim belajar ke negeri Cina yang pastilah terkait dengan upaya penguasaan sains awa'il ini. Mungkin perlu ditanyakan mengapa sains awa'il pada peradaban Islam klasik umumnya adalah sains alam dan matematika sementara ilmu-ilmu sosial hampir tak pernah disebut. Ada dua alasan utama. Pertama, ilmu-ilmu sosial dan humaniora banyak dirintis dan dikembangkan oleh sarjana-sarjana Muslim sendiri. Al-Biruni adalah sarjana pertama yang menulis lengkap tentang sejarah dan kebudayaan Hindu India yang menjadi referensi utama hingga awal abad ke-20, yaitu kitab Tarikh al-Hind (yang diterjemahkan menjadi al-Biruni's India). Ibn Khaldun dengan Muqaddimah-nyadiakui sebagai peletak dasar ilmu sosiologi. Sedangkan ilmu sejarah dan hukum tentu dengan sendirinya harus telah dikuasai oleh sarjana Muslim ketika menekuni ilmu hadis dan fikih, sebagaimana yang telah kita bahas sebelumnya. Alasan kedua, peradaban-peradaban pra-Islam itu sendiri memang tidak mewariskan ilmu-ilmu sosial. Yunani memang banyak meninggalkan seni sastra dan drama tetapi ditolak total oleh sarjana Muslim karena ia penuh dengan mitos, takhyul, kisah-kisah yang tragis, dan sikap negatif terhadap makna hidup; sesuatu yang bertentangan diametral dengan nilai-nilai Islam.

Tasawuf ('irfan) adalah salah satu disiplin yang lahir dan berkembang dalam rahim kebudayaan Islam. Seyyed Hossein Nasr menyebut tasawuf sebagai dimensi spiritual-esoteris ajaran Islam. ${ }^{7}$ Menurut Nasr, terdapat tiga dimensi ajaran Islam, yaitu syari'ah (hukum suci), tariqah (jalan), dan haqiqah (kebenaran); yang ketiganya berturut-turut berkorespondensi dengan islam, iman, dan ihsan. ${ }^{8}$ Muthahhari dalam buku-bukunya menyebutnya dengan term 'irfan. Menurut Muthahhari, 'irfan dapat didekati dari dua dimensi, yaitu sosial dan akademis. Sebagai kelompok sosial, para pesuluk ini disebut sufi, dan ketika merujuk sebagai sebuah disiplin akademis mereka disebut 'urafa. Karena itu, dalam pembahasan disiplin ilmu-ilmu Islam, lebih tepat menyebutnya 'irfan sebagai sebuah cabang kebudayaan

${ }^{5}$ Esai Nasr ini bisa dibaca dalam buku History of Islamic Philosophy (Jilid Satu) yang dia edit bersama Oliver Leaman (London: Routledge, 1996), h. 27-39.

${ }^{6}$ Bisa dibaca pada Kisab-kisah Imam Ali bin Abi Thalib karya Ali Shofi (Jakarta: Penerbit Lentera, 2002)

${ }^{7}$ Ulasan yang komprehensi tentang sufisme dapat dibaca dalam karya Seyyed Hossein Nasr, Sufi Essays (Chicago: ABC International Group, 1999)

${ }^{8}$ Seyyed Hossein Nasr, Islamic Life and Thought (London: : George Allen \& Unwin, 1981) 
ilmiah Islam. Sebagai suatu disiplin ilmiah dan akademis, 'irfan memiliki dua cabang, yakni: irfan 'ilmi (tasawuf teoritis) dan 'irfan 'amali (tasawuf praktis). 'Irfan teoritis menggunakan pendekatan/bahasa filosofis untuk mengekspresikan pengalaman mistiknya (kasyf). 'Irfan praktis, yang mirip dengan pembinaan akhlak, menapaki perjalanan spiritual sayr wa suluk melalui tahap-tahap (bal) dan stasiunstasiun (maqam) perkembangan jiwa. ${ }^{9}$

\section{Integrasi Ilmu}

Uraian di muka yang mengulas secara ringkas satu per satu ketujuh tradisi keilmuan yang mengkonstitusi peradaban Islam bermaksud untuk menunjukkan adanya keterpaduan yang kokoh di antara tradisi-tradisi keilmuan tersebut. Ketujuh tradisi keilmuan Islam it harus dibaca dalam 'satu helaan napas' dalam atmosfir wahyu yang menginpsirasi para sarjana Muslim membangun tonggaktonggak ilmiah peradaban Islam. Karena berakar pada pandangan-dunia Tauhid yang memahami realitas bersifat unipolar dan uniaksial, maka pengenalan dan pemahaman terhadap realitas melalui pintu-pintu pelbagai tradisi keilmuan akan mengacu kepada Kebenaran realitas yang sama. Implikasinya adalah terdapat keterpaduan yang inheren di antara tradisi keilmuan tersebut. Kesalingterkaitan ilmu-ilmu itu ibarat sebuah pohon. Wahyu al-Qur'ân dan hadis adalah seperti akar dan batang dari pohon tradisi keilmuan Islam. Sedangkan ilmu-ilmu budaya, sains, dan insitusi-institusi sosial adalah seperti cabang-cabang pohon, di antaranya ada yang lebih dekat kepada batang dan yang lainnya lebih jauh. Namun, semuanya merupakan bagian dari sebuah organisme yang tumbuh dari akar.

Terintegrasinya ilmu-ilmu dalam Islam merupakan manifestasi dari pandangan Tauhid yang melihat seluruh objek telaah berbagai ilmu itu sebagai ayat-ayat Tuhan. Tidak mungkin berbagai tradisi keilmuan itu, jika dilacak sampai ke akar-akar kebenarannya, saling bertolak belakang atau kontradiktif lantaran "sesama ayat Tuhan" pastilah saling mendukung. Jika terjadi kontradiksi di antara berbagai tradisi keilmuan tersebut, maka hal itu dapat dipastikan berasal dari penafsiran dan pemahaman sang sarjana Muslim itu sendiri.

Seorang sarjana asal Palestina yang menjadi guru besar pada Department of Religion di Temple University, Ismail Raji al-Faruqi (1921-1986), menjelaskan bahwa sebagai intisari peradaban Islam, Tauhid mempunyai dua segi/dimensi: metodologis dan konseptual. Dalam dimensi konseptual yang menentukan isi peradaban Islam. Tauhid adalah prinsip pertama metafisika, etika, estetika, dan masyarakat. Sedang dimensi metodologis yang menentukan bentuk peradaban Islam meliputi tiga prinsip, yaitu kesatuan, rasionalisme, dan toleransi. Prinsip kesatuan menegaskan bahwa tidak ada peradaban tanpa kesatuan. Lebih jauh al-Faruqi menguraikan,

Jika unsur-unsur peradaban tidak bersatu, berjalin, dan selaras dengan lainnya, maka unsur-unsur itu bukan membentuk peradaban, melainkan himpunan campur-aduk. Peradaban Islam menempatkan unsur-unsur dalam bangunan rapi dan mengatur eksistensi serta hubungannya berdasarkan pola yang seragam. Unsurunsur itu ada yang asli dan ada yang berasal dari luar. Tidak ada peradaban yang tidak mengambil unsur dari luar. Yang penting adalah bahwa peradaban mencerna unsur itu, yaitu mempola kembali bentuk dan hubungannya sehingga menyatu ke dalam sistemnya sendiri. "Membentuk" unsur itu dengan bentuknya sendiri pada esensinya mengubahnya menjadi realitas baru sehingga unsur itu tak lagi eksis sebagai unsur itu sendiri, namun sebagai komponen integral peradaban baru. Dalam peradaban Islam, unsur-unsur pembentuk itu, baik unsur material, struktural atau relasional diikat oleh tauhid sebagai prinsip utama. ${ }^{10}$

${ }^{9}$ Murtadha Muthahhari, Understanding Islamic Sciences (London: ICAS Press, 2002)

${ }^{10}$ Lihat karya Isma’il Raji al-Faruqi bersama istrinya Lois Lamya al-Faruqi, Atlas Budaya Islam: Menjelajab Khazanah Peradaban Gemilang (terjemahan dari The Cultural Atlas of Islam oleh Ilyas Hasan) (Bandung: Penerbit Mizan, 1998), h. 112 - 126 
Pandangan integral-holistik yang dilukiskan oleh al-Faruqi di muka telah mendorong para sarjana Muslim untuk menelaah berbagai tradisi keilmuan. Seorang sarjana Muslim klasik dapat mereguk dan menguasai berbagai cabang ilmu. Ibn Sînâ misalnya, merupakan ahli kedokteran dan fisika, namun juga sekaligus seorang filsuf, bâfidz al-Qur'ân, dan sufi. Jabir ibn Hayyan yang dikenal sebagai Bapak Kimialantaran mendirikan laboratorium kimia pertama di dunia adalah juga seorang astronom, matematikawan, kosmolog, dan sufi. Al-Bîrûnî yang dikenal fisikawan dan Bapak Eksperimentalis yang pertama kali menghitung keliling bumi dan mengukur massa jenis bebeberapa logam adalah juga seorang matematikawan, astronom, epistemolog, sosiolog, dan penulis perbandingan agama yang banyak dipuji karena objektivitasnya.

\section{Klasifikasi Ilmu}

Terkait dengan kenyataan bahwa integrasi ilmu-ilmu merupakan salah satu karakter peradaban Islam, Seyyed Hossein Nasr mengaitkan hal itu dengan sebuah tradisi yang umum berlaku di di kalangan sarjana Muslim, yaitu menyusun klasifikasi ilmu. Klasifikasi Islam atas ilmu-ilmu didasarkan pada hirarki dan kesalinghubungan antardisiplin ilmu yang memungkinkan realisasi ketunggalan dalam kemajemukan. Menurut Nasr dalam pengantarnya terhadap buku Osman Bakar yang berjudul Classification of Knowledge in Islam (Kuala Lumpur, 1992) ${ }^{11}$, ditemukannya tingkatan dan hubungan yang tepat antar berbagai disiplin ilmu merupakan tujuan para tokoh intelektual Islam terkemuka, dari teolog hingga filsuf, dari sufi hingga sejarawan, sehingga banyak di antara mereka mencurahkan energi intelektualnya pada masalah klasifikasi ilmu. Pemahaman masalah ini juga sangat penting, kata Nasr, karena ia merupakan salah satu kunci utama untuk memahami tradisi intelektual Islam.

Dengan mengelaborasi klasifikasi ilmu yang disusun oleh tiga pemikir Muslim, yaitu al-Farabi (870-950), al-Ghazali (1058-1111), dan Quthb al-Din al-Syirazi (1236-1311), Osman Bakar mencoba menggali dan menbedah latar belakang filosofis yang mendasari penyusunan klasifikasi ilmu dari ketiga pemikir tersebut. Menurut Osman Bakar, klasifikasi ilmu yanng dirancang oleh ketiga pemikir tersebut menggambarkan mazhab filsafat dan intelektual Islam beserta gagasan-gagasan religius masingmasing tokoh. Klasifikasi al-Farabi merupakan penjelmaan wawasan filosofisnya yang menekankan kesatuan dan hirarki ilmu. Sebagai filsuf, matematikawan, pakar logika, ahli musik, pemikir politik, dan saintis umumnya, al-Farabi memiliki wawasan dan kedalaman pengetahuan serta minat yang kuat untuk mendemonstrasikan persaudaraan sekaligus strata ilmu-ilmu.

Al-Farabi, menurut Osman Bakar, menggunakan tiga basis fundamental dalam menyusun hierarki ilmu-ilmu, yaitu: metodologis, ontologis, dan etis. Sedangkan klasifikasi al-Ghazali didasarkan pada pembagian antara ilmu keagamaan (syar'iyah) dan ilmu rasional ('aqliyab) dengan konsepsi mutakallimun tentang hubungan antara wakyu dan akal yang satu sama lain eksklusif. Sementara Quthb al-Din al-Syirazi yang muncul setelah al-Farabi dan al-Ghazali melakukan sintesis terhadap klasifikasiklasifikasi pendahulunya. Pengikut mazhab iluminasionistik Suhrawardi tetapi setia dengan penalaran diskursif Ibn Sina ini, membagi ilmu menjadi ilmu-ilmu bikmat (filosofis) dan ilmu-ilmu ghayr hikmat (non-filosofis). Quthb al-Din menyatakan ilmu filosofis sebagai ilmu mengenai sifat-sifat dasar dan universal alam raya, sedang ilmu non-filosofis adalah ilmu-ilmu yang berkaitan dengan syari’ah, yang berbeda setiap zaman dan kebudayaan. Karena itu, jelas Osman Bakar, Quthb al-Din tidak

${ }^{11}$ Lihat Osman Bakar, Classification of Knowledge in Islam: A Study in Islamic Philosophy of Science (Kuala Lumpur: Institute for Policy Research, 1992). Karya ini sudah diterjemahkan oleh Penerbit Mizan dengan judul Hierarki Ilmu: Membangun RangkaPikir Islamisasi Ilmu (Bandung, 1997) 
mengelaborasi perbedaan antara agama dan filsafat dalam kerangka perbedaan antara wahyu dan akal. Dalam hal ini, dia mewarisi pandangan filosofis al-Farabi yang menekankan universalitas filsafat.

Terlepas dari keragaman klasifikasi ilmu yang disusun oleh sejumlah pemikir Muslim, adanya klasifikasi ilmu itu selain merupakan manifestasi dari keutuhan pandangan yang integral-holistik para sarjana Muslim, juga sebuah bentuk tanggung jawab epistemologis dan etis untuk menjaga keharmonisan, proporsionalitas, dan keseimbangan ilmu-ilmu. Seperti juga sebuah cabang tak terus tumbuh tanpa hingga, begitu pula suatu disiplin ilmu tidak selayaknya dipelajari sedemikian rupa sehingga mengabaikan disiplin ilmu yang lain. Klasifikasi ilmu ini merupakan warisan berharga tradisi intelektual Islam yang perlu dilestarikan dan diaktualisasikan dalam sistem pendidikan kontemporer. Menurut Nasr, subjek ini pun merupakan kunci bagi sistem pendidikan Islam untuk mencegah para pendidik Muslim kontemporer melepaskan diri dari kekacauan dan kerancuan yang berkecamuk dalam kurikulum pendidikan saat ini, dengan peniruan buta terhadap model-model Barat yang sering terbaur secara ad hoc dengan berbagai acuan yang tetap hidup dalam sistem madrasah.

Tradisi klasifikasi ilmu inilah yang sekarang hilang pada sarjana modern, di Barat atau pun di Timur dan Islam. Ketiadaan klasifikasi ilmu seperti itu yang menciptakan terjadinya fragmented knowledge dan ketidakseimbangan ilmu-ilmu. Sejumlah disiplin ilmu tertentu seperti sains alam dan matematika dikembangkan, sementara disiplin ilmu seperti sains sosial dan humaniora ditelantarkan. Bahkan, sejalan dengan paham positivisme yang menguasai pemikiran modern, disiplin ilmu-ilmu sosial dan humaniora harus ditundukkan dan disubordinasikan di bawah metode empirisme sains alam. Akibatnya, muncullah aliran-aliran ilmu sosial dan humaniora yang asing dengan esensi kemanusiaan itu sendiri; misalnya aliran behaviorisme dalam psikologi yang tidak mengakui eksistensi jiwa manusia dan memandang manusia tak lebih seperti hewan yang lebih kompleks dari kucing dan monyet.

Adanya fragmented knowledge pun pada gilirannya melahirkan pandangan-dunia yang terpecah, fragmented personality(kepribadian yang terbelah), dan fragmented society. Kepribadian yang terbelah ini dengat sangat bagus dipaparkan oleh RD Laing dalam bukunya The Divided Self (Penguin Books, London, 1990). Melalui analisis fenomenologis-eksistensial, Laing menemukan bahwa peradaban modern yang positivistik telah menekan setiap bentuk transendensi kemanusiaan kita sedemikian sehingga diri kita terasing dari diri sendiri dan yang lain (the others) sebagai yang riil. Ironis, papar Laing, setiap orang yang mengaku kehilangan jiwanya dianggap gila (implikasi penolakan positivisme terhadap eksistensi jiwa); sementara orang yang menyatakan manusia adalah mesin akan dijuluki sebagai saintis besar.

Adapun ketidakseimbangan ilmu-ilmu melahirkan praktik penganakemasan beberapa disiplin ilmu, dan sebaliknya, penganaktirian disiplin-disiplin ilmu lainnya. Fenomena ini dengan tajam dikupas oleh Herbert Marcuse. Dalam bukunya yang terkenal One Dimensional Man (Beacon Press, Boston, 1991), Marcuse memaparkan bagaimana pola pikir positivistik yang hanya mengenal satu dimensi, yaitu aspek fisik manusia dalam dialektika positif, telah mereduksi kemampuan refleksi kritis manusia untuk mencari makna-makna tersembunyi di balik fenomena-fenomena.

\section{Penutup}

Mungkin kondisi bangsa kita dewasa ini tidak akan separah sekarang jika sistem pendidikan kita bersikap adil dan memiliki visi integrasi dan klasifikasi ilmu beserta perhatian yang proporsional terhadap disiplin-disiplin ilmu, sesuai dengan posisi ilmu-ilmu tersebut dalam melayani kemanusiaan kita. Selama ini ilmu-ilmu agama, budaya, filsafat, moral, dan sastra atau bahkan sains murni kerap 
diabaikan dan terkalahkan oleh ilmu-ilmu praktis seperti ekonomi dan keteknikan. Dimensi kemanusiaan dan keberadaban pembangunan negara kita hilang ditelan oleh pragmatisme dan sikap oportunistik.

Kekeliruan filosofis yang mendasar itu dapat ditelusuri di GBHN (Garis-Garis besar Haluan Negara) masa Orde Baru selama 25 tahun lebih yang menempatkan manusia hanya sebagai sumber daya yang ketiga di bawah kekayaan alam, flora dan fauna. Keadaan ini berarti lebih buruk daripada apa yang dirisaukan oleh Seyyed Hossein Nasr tentang kurikulum pendidikan di negeri-negeri Muslim yang kehilangan visi hirarki pengetahuan sehingga menempatkan studi tentang ketuhanan atau kemanusiaan selevel dengan studi tentang ekonomi atau pariwisata. Kenapa lebih buruk? Yang dirisaukan oleh Nasr adalah praktek mempersamakan semua bidang kajian, sementara kita justru menempatkan studi kemanusiaan di bawah studi kecakapan teknis.

Konsekuensinya, sumber daya manusia (SDM) masyarakat kita di bidang-bidang kemanusiaan jauh tertinggal. Moralitas dan kebudayaan masyarakat kita pun kini carut-marut dan mengalami disorientasi dan pembusukan. Ribuan sarjana kita lahirkan setiap tahun namun tidak dengan sendirinya memperbaiki kondisi masyarakat dan bangsa karena tidak terbangunnya integritas moral dan kepribadian yang berkarakter. Para pemimpin kita di legislatif dan eksekutif - yang umumnya adalah para sarjana - hanya memandang rakyat sebagai 'voter' (peserta pemilu) atau 'supporter' (pendukung partai/kelompok), bukan sebagai 'manusia yang utuh'. Mereka telah lama kehilangan visi kemanusiaan sejak di bangku sekolah. Akibatnya, mereka tidak segan-segan mengelabui rakyat dan melupakannya setelah merenggut kekuasaan.

\section{DAFTAR PUSTAKA}

Abdullah, Taufik (ed.), (2002). Ensiklopedi Tematis Dunia Islam Jilid 4 tentang Pemikiran dan Peradaban, Jakarta: PT Ichtiar Baru Van Hoeve.

Bakar, Osman, (1992). Classification of Knowledge in Islam: A Study in Islamic Philosophy of Science, Kuala Lumpur: Institute for Policy Research.

Faruqi, Isma'il Raji al- dan Lois Lamya al-Faruqi, (1998). Atlas Budaya Islam: Menjelajah Khazanah Peradaban Gemilang (terjemahan dari The Cultural Atlas of Islam oleh Ilyas Hasan). Bandung: Penerbit Mizan.

Madjid Nurcholish, (1997). Kaki Langit Peradaban Islam, Jakarta: Paramadina.

Muthahhari, Murtadha, (2002). Understanding Islamic Sciences, London: ICAS Press.

Nasr, Seyyed Hossein dan Oliver Leaman, (1996). History of Islamic Philosophy, London: Routledge.

Nasr, Seyyed Hossein, (1981). Islamic Life and Thought, London: : George Allen \& Unwin. , (1987). Traditional Islam in the Modern World, London: Kegan Paun International.

—, (1999). Sufi Essays, Chicago: ABC International Group.

Shofi, Ali (2002). Kisah-kisah Imam Ali bin Abi Thalib, Jakarta: Penerbit Lentera. 